ISSN. 2621-9832

JURNAL MathEdu (Mathematic Education Journal) http://journal.ipts.ac.id/index.php/MathEdu

Vol. 4 No. 3 November 2021

\title{
ANALISIS KEMAMPUAN KOMUNIKASI MATEMATIS SISWA DITINJAU DARI MINAT BELAJAR SISWA PADA PEMBELAJARAN DARING DIMASA PANDEMI COVID-19
}

\author{
Oleh : \\ Roslian Lubis $^{1}$, Muhammad Syahril Harahap ${ }^{2}$, Pia Paramita Tarihoran \\ Institut Pendidikan Tapanuli Selatan (IPTS) Padangsidimpuan
}

\begin{abstract}
The aims of this study is to describe students' mathematical communication ability in term of learning interest in learning online during the Covid-19. The approach of the research used qualitative descriptive with 11 students and 1 mathematics teacher at the eighth grade students as the subject of the research which taken by using purposive sampling technique. Questionnaire, test, and interview were used in collecting the data. The result of the research shows average of students' mathematical communication ability 57.48 (average category) and average of students' learning interest is 70.36 (good category). Furthermore, the result of the research shows students' learning interest is high then students' mathematical communication ability is high, students' learning interest is average then students' mathematical communication ability is average, students' learning interest is low then students' mathematical communication ability is low.
\end{abstract}

Keywords: mathematical communication ability, learning interest, Covid-19, learning online

Abstrak
Tujuan dari penelitian ini adalah untuk mendeskripsikan kemampuan komunikasi matematis siswa dalam kaitannya dengan minat belajar online selama Covid-19. Pendekatan penelitian menggunakan deskriptif kualitatif dengan 11 siswa dan 1 guru matematika kelas VIII sebagai subjek penelitian yang diambil dengan menggunakan teknik purposive sampling. Angket, tes, dan wawancara digunakan untuk mengumpulkan data. Hasil penelitian menunjukkan rata-rata kemampuan komunikasi matematis siswa 57,48 (kategori sedang) dan rata-rata minat belajar siswa adalah 70,36 (kategori baik). Selanjutnya hasil penelitian menunjukkan minat belajar siswa tinggi kemudian kemampuan komunikasi matematis siswa tinggi, minat belajar siswa sedang, kemampuan komunikasi matematis siswa rata-rata, minat belajar siswa rendah, kemudian kemampuan komunikasi matematis siswa rendah.

Kata kunci: kemampuan komunikasi matematis, minat belajar, Covid-19, pembelajaran daring

\section{PENDAHULUAN}

Pendidikan memiliki peran penting dalam kehidupan manusia. Salah satunya sebagai media yang berfungsi menjadikan manusia lebih baik dari sebelumnya. Kemajuan dan kemunduran bangsa dapat dilihat dari kualitas pendidikan dalam bangsa indonesia itu sendiri. Berdasarkan UUD Republik Indonesia No. 20 Tahun 2003 tentang Sistem Pendidikan Nasional menyatakan, bahwa "pendidikan adalah usaha sadar da terencana untuk mewujudkan suasana belajar dan proses pembelajaran agar peserta didik secara aktif mengembangkan potensi dirinya untuk memiliki kekuatan spritual keagamaan, pengendalian diri, kepribadian, kecerdasan akhlak mulia, serta keterampilan dirinya, masyarakat, bangsa dan negara”.

Kemampuan berasal dari kata dasar mampu atau disebut juga dengan kesanggupan, sehingga kemampuan dapat menyatakan nama dari seseorang, tempat, atau semua benda segala yang di bendakan. Jadi kemampuan adalah kapasitas seorang individu untuk melakukan beragam tugas dalam suatu pekerjaan. Berdasarkan pengertian diatas, peneliti dapat menyimpulkan bahwa kemampuan adalah yang mempelajari ide-ide pada matematika dituntut mampu mengkomunikasikan simbol tersebut kepada orang lain.

Komunikasi adalah suatu cara untuk mengucapkan atau mengatakan sesuatu. Komunikasi dapat terjadi antara siswa dengan guru, dan siswa dengan lingkunganya. Dan pengertian matematika adalah bahasa simbol, setiap orang mempelajari ide-ide pada matematika dituntut mampu mengkomunikasikan simbol tersebut pada orang lain. Berdasarkan pengertian diatas bahwa peneliti menyimpulkan bahwa matematika adalah salah satu mata pelajaran yang harus dilalui dalam jenjang pendidikan, matematika merupakan bahasa simbol, setiap orang 
ISSN. 2621-9832

JURNAL MathEdu (Mathematic Education Journal) http://journal.ipts.ac.id/index.php/MathEdu

Vol. 4 No. 3 November 2021

menajamkan cara berpikir siswa, sebagai alat untuk menilai pemahaman siswa, membantu pengetahuan matematinya, memajukan penalaranya, membangun kemampuan diri, meningkatkan keterampilan sosialnya, serta bermamfaat dalam mendirikan komunitas matematik"

Kemampuan komunikasi matematis merupakan salah satu tujuan pembelajaran matematika yang banyak diterapkan dalam pembelajaran matematika.. Berikut ini menurut Wijayanto, dkk (2018:98) menyatakan bahwa "kemampuan komunikasi matematis dalam pembelajaran matematika yaitu untuk membantu siswa bahwa kemampuan adalah sebagai suatu dasar seseorang yang dengan sendirinya berkaitan dengan pelaksanaan pekerjaan secara efektif atau sangat berhasil.

Kemampuan komunikasi matematis siswa merupakan kemampuan yang diperlukan dalam belajar matematika dan sangatlah penting untuk oleh siswa di indonesia dalam menghadapi masalah dalam kehidupan siswa. Kemampuan komunikasi matematis siswa dipengaruhi beberapa faktor salah satunya minat belajar siswa.

Minat adalah perhatian, rasa suka, ketertarikan seseorang (siswa) terhadap belajar yang ditunjukkan melalui kuantitas, partisifasi dan keaktifan dalam belajar. Berikut ini upaya peningkatan minat belajar menurut Ricardo dan Meilani (2017: 190) menyatakan bahwa " upaya peningkatan minat belajar dapat ditingkatkan dengan 3 langkah yaitu : 1) dengan mengartikulasikan tujuan pembelajaran, 2) dengan menyoroti berbagai penerapan pengetahuan dan keterampilan di dunia nyata, 3) guru dapat menghubungkan pembelajaran dengan minat pribadi siswa. Belajar adalah suatu proses usaha yang dilakukan seseorang untuk memperoleh suatu perubahan tingkah laku yang baru secara keseluruhan, sebagai hasil pengalamanya sendiri dalam secara keseluruhan sebagi hasil pengalaman interaksi antara guru dan siswa.

Minat belajar adalah suatu rasa suka dalam belajar tanpa ada yang menyuruh. Hal ini menunjukkan bahwa minat belajar dapat menjadi motivasi yang mendorong seseorang untuk melakukan apa yang diinginkan. Minat belajar mempunyai peranan penting dalam perperkembangan belajar siswa yang menaruh minat pada suatu bidang tertentu, maka akan berusaha lebih keras dalam menekuni bidang tersebut dibanding siswa yang tidak menaruh minat.

Pada tahun 2020 akibat adanya Virus Corona (Covid-19), situasi membuat kehidupan menjadi terkendala ekonomi termasuk aspek pendidikan karena virus tersebut dengan cepat menyebar atau menular dari manusia ke manusia melalui sentuhan ataupun saat bersin maupun batuk. Sehingga, segala aktivitasyang dilakukan diluar rumah khususnya terhadap siswa yang dilakukan tatap muka harus dihentikan dimana situasi saat ini menuntut siswa untuk waspada dengan lingkungan sehari-hari. Selanjutnya Mustakim (2020:3) menyatakan bahwa "penggunaan media online, atau media berbasis multimedia merupakan salah satu solusi untuk membuat peserta didik mampu memahami materi pelajaran dengan baik. Media online yang digunakan seperti youtobe, whatsaap group, geoggle clasroom, dan quizzes. Berdasarkan pengertian diatas, peneliti menyimpulkan bahwa pembelajaran daring adalah pembelajaran tanpa tatap muka secara langsung antara guru dan siswa tetapi dilakukan secara online yang menggunakan jaringan internet.

Kemampuan komunikasi matematis dan minat belajar siswa sangat diperlukan untuk kesuksesan belajar, karena dengan kemampuan komunikasi matematis dan minat belajar siswa memungkinkan siswa untuk mampu menggunakan bahasa matematis berikutnya. Siswa dapat didorong untuk melakukan suatu melakukan suatu kemampuan komunikasi matematis dan minat belajar, dengan cara meningkatkan kesadaran mereka bahwa kemampuan komunikasi matematis dan minat belajar diperlukan untuk meningkatkan prestasi akademik

Melihat betapa pentingnya kemampuan komunikasi matematis dan minat belajar siswa untuk kemajuan hasil belajar siswa dan berpikir siswa yang nantinya berpengaruh pada tingkat kemampuan matematikanya, maka perlu dilakukan upaya perbaikan misalnya dengan pelatihan guru dan pelatihan kesadaran siswa dalam belajar. Dalam hal ini peneliti akan memaparkan tentang judul Analisis Kemampuan Komunikasi Matematis Siswa Ditinjau Dari Minat Belajar Siswa Pada Pembelajaran Daring Dimasa Pandemi Covid-19.

\section{METODE PENELITIAN}

Metode penelitian dalam penelitian ini menggunakan metode penelitian kualitatif. Menurut Mukhtar (2010:18) menyatakan bahwa "Metode penelitian pada dasarnya merupakan cara ilmiah untuk mendapatkan data dengan tujuan dan kegunaan tertentu". Sedangkan menurut Arikunto (2009:62) menyatakan bahwa "Metode penelitian adalah bagian pokok dalam program penelitian". Sedangkan Sugiyono (2017:15), menyatakan bahwa "Metode penelitian kualitatif adalah metode penelitian yang berlandaskan pada filsafat postpositivisme, digunakan untuk meneliti pada objek yang alamiah dalam mengumpulkan informasi atau data dengan tujuan tertentu".

\section{Objek dan Informan Penelitian}

Objek dalam penelitian ini adalah kemampuan komunikasi matematis siswa ditinjau dari minat belajar siswa pada pembelajaran daring dimasa pandemi covid-19. Informan dalam penelitian ini yaitu siswa/siswi kelas 
ISSN. 2621-9832

JURNAL MathEdu (Mathematic Education Journal) http://journal.ipts.ac.id/index.php/MathEdu

Vol. 4 No. 3 November 2021

VIII (VIII.IA) sebanyak 11 orang dan guru yang berada di SMP Negeri 1 Sosorgadong. Pemilihan informan ini dilakukan dengan teknik sampling purposive sampling. Purposive sampling adalah teknik pengambilan sampel atau sumber data dengan pertimbangan tertentu (Sugiyono, 2017:300).

\section{Data dan Sumber Data}

Data primer dalam penelitian ini adalah hasil tes soal kemampuan komunikasi matematis siswa kelas VIII.IA, hasil angket yang disebarkan kepada siswa, dan hasil wawancara dengan guru mata pelajaran matematika. Sedangkan yang menjadi sumber data sekunder dalam penelitian ini adalah data keadaan siswa, jumlah sarana dan prasarana, dan letak geografis, yang diperoleh dari Kantor Tata Usaha SMP Negeri 1 Sosorgadong. Sumber data primer dalam penelitian ini adalah nilai siswa dari kemampuan komunikasi matematis dan minat belajar siswa. Sedangkan yang menjadi sumber data sekunder penelitian ini yang diperoleh dari dokumentasi, buku pendidikan, dan jurnal pendidikan.

\section{Instrumen Penelitian}

Adapun instrumen yang digunakan dalam penelitian ialah sebagai berikut :

1. Lembar Wawancara

Wawancara adalah suatu salah satu bentuk teknik pengumpulan data dimana pewawancara (peneliti atau yang diberi tugas melakukan pengumpulan data) dalam mengumpulkan data mengajukan suatu pertanyaan kepada yang di wawancarai (Sugiyono 2014 : 224). Dalam penelitian ini, peneliti melakukan wawancara secara semiterstruktur dan dilakukan secara tatap muka. Wawancara ini digunakan untuk mengukur kemampuan komunikasi matematis siswa dan minat belajar siswa dalam menjawab soal tes yang sudah dikerjakan oleh siswa.

\section{Angket}

Penyusunan angket dalam penelitian menggunakan skala Likert. Menurut Sugiyono (2011:136-141), menyatakan "Skala Likert adalah skala yang mengukur sikap, pendapat, persepsi seseorang untuk sekelompok orang tentang fenomena sosial. Skala 0-4, dengan pilihan yang terdiri dari Selalu $=4$, Sering $=3$, Kadang-kadang $=2$, dan Tidak Pernah =0". Adapun indikator dari minat belajar siswa yaitu : 1) perhatian, 2) Ketertarikan, 3) Rasa Senang, 4) Keterlibatan (Ricardo dan Meilani 2017:190). Angket ini digunakan untuk mengukur minat belajar siswa pada pembelajaran daring dimasa pandemi covid-19.

\section{Tes}

Tes dalam penelitian ini adalah untuk mengukur kemampuan komunikasi matematis siswa pada materi lingkaran di kelas VIII.IA di SMP Negeri 1 Sosorgadong. Adapun indikator dari kemampuan komunikasi matematis adalah : a) Menghubungkan benda nyata, gambar, diagram, dan tabel ke dalam ide matematika, b) Menejelaskan ide, situasi, dan relasi matematika, secara lisan atau tulisan dengan benda nyata, gambar, grafik, dan aljabar, c) Menyatakan peristiwa sehari-hari dalam bahasa atau simbol matematika (Raja, dkk 2020).

\section{Teknik Keabsahan Data}

Untuk menetapkan keabsahan data diperlukan triangulasi teknik. Triangulasi teknik dilakukan agar data yang diperoleh dari informan peneliti yang menjadi sumber dari primer untuk lebih valid, konsisten, tuntas, dan pasti sehingga dapat dianalisis dan ditarik kesimpulan hubungan kemampuan komunikasi matematis dan minat belajar siswa.

\section{Teknik Analisis Data}

\section{Reduksi Data}

Reduksi data berarti merangkum, memilih hal-hal pokok, memfokuskan pada hal-hal yang penting, dicari temadan polanya dan membuang yang tidak perlu (Sugiyono, 2017:324). Dalam penelitian ini aspek yang direduksi adalah hasil dari tes, wawancara, maupun angket juga terkait dengan kemampuan komunikasi matematis dan minat belajar.

\section{Penyajian Data}

Penyajian data sebagai sekumpulan informasi tersusun yang memberi kemungkinan adanya penarikan kemampuan komunikasi matematis dan minat belajar siswa.kesimpulan dan pengambilan tindakan. Berdasarkan data yang ada, maka selanjutnya peneliti akan menggambarkan, menjelaskan atau menafsirkan serta menyampikan ke dalam bentuk narasi maupun presentasi yang dapat dipahami dengan jelas.

3. Menarik Kesimpulan

Menarik kesimpulan yaitu ketika kegiatan pengumpulan data dilakukan, seorang penganalisis kualitatif mulai mencari benda-benda, mencatat keteraturan, pola-pola, penjelasan konfigurasi-konfigurasi yang mungkin, alur 
ISSN. 2621-9832

JURNAL MathEdu (Mathematic Education Journal) http://journal.ipts.ac.id/index.php/MathEdu Vol. 4 No. 3 November 2021

sebab akibat, dan proposisi. Penarikan kesimpulan dari kemampuan komunikasi matematis siswa, minat belajar siswa selama pembelajaran daring dimasa pandemi covid-19.

\section{HASIL DAN PEMBAHASAN}

\section{Hasil Penelitian Minat Belajar}

Setelah mengadakan penelitian terkait hasil penelitian yang menggunakan angket yang dilakukan pada tanggal 30 Maret 2021. Dengan angket ini dapat mengetahui nilai siswa dan yang tergolong dalam mempunyai kemampuan tinggi, sedang, dan rendah. Berikut ini akan dipaparkan tabel dari hasil nilai siswa kelas VIII.IA SMP Negeri 1 Sosorgadong.

Tabel 1

Hasil Nilai Minat Belajar Siswa Berdasarkan Angket

\begin{tabular}{|c|c|c|c|c|c|c|c|}
\hline \multirow[t]{2}{*}{ No } & \multirow{2}{*}{ Inisial } & \multicolumn{4}{|c|}{ Indikator } & \multirow[t]{2}{*}{ Nilai } & \multirow{2}{*}{$\begin{array}{c}\text { Kategori } \\
\text { Kemampuan Siswa }\end{array}$} \\
\hline & & 1 & 2 & 3 & 4 & & \\
\hline 1 & AYS & 6 & 6 & 6 & 7 & 71 & Baik \\
\hline 2 & AAS & 6 & 6 & 6 & 7 & 67 & Baik \\
\hline 3 & $\mathrm{AS}$ & 6 & 6 & 6 & 7 & 63 & Cukup \\
\hline 4 & $\mathrm{BT}$ & 6 & 6 & 6 & 7 & 78 & Baik \\
\hline 5 & $\mathrm{CP}$ & 6 & 6 & 6 & 7 & 54 & Kurang \\
\hline 6 & DS & 6 & 6 & 6 & 7 & 68 & Baik \\
\hline 7 & DM & 6 & 6 & 6 & 7 & 87 & Sangat Baik \\
\hline 8 & EM & 6 & 6 & 6 & 7 & 76 & Baik \\
\hline 9 & GM & 6 & 6 & 6 & 7 & 66 & Baik \\
\hline 10 & MS & 6 & 6 & 6 & 7 & 67 & Baik \\
\hline 11 & $\mathrm{NS}$ & 6 & 6 & 6 & 7 & 77 & Baik \\
\hline \multicolumn{2}{|c|}{ Jumlah } & & & & & $\frac{774}{11}=70,36$ & $\underline{\text { Baik }}$ \\
\hline
\end{tabular}

Berdasarkan tabel diatas, mengenai hasil dari angket minat belajar siswa di SMP Negeri 1 Sosorgadong yang berada pada kategori baik. Dimana siswa tersebut ada yang minat belajarnya sangat baik, ada yang minat belajarnya baik, ada minat belajarnya cukup, dan ada juga minat belajarnya kurang. Hasil dari angket minat belajar siswa yang dijawab oleh siswa kelas VIII.IA, dengan menggunakan indikator dari minat belajar siswa yaitu perhatian, ketertarikan, rasa senang, dan keterlibatan. Dimana pernyataan dari angke minat belajar tersebut ada 25 pernyataan. Dalam indikator yang pertama minat belajar yaitu perhatian yang terdiri dari enam pernyataan, indikator minat belajar yang kedua, yaitu ketertarikan yang terdiri dari enam pernyataan, indikator minat belajar yang ketiga yaitu rasa senang yang terdiri enam pernyataan dan indikator minat belajar yang keempat yaitu keterlibatan yang terdiri dari 7 pernyataan. Dari tabel diatas, hasil jawaban siswa tersebut ratarata menjawab pernyataan sesuai dengan indikator minat belajar siswa.

\section{Hasil Kemampuan Komunikasi Matematis}

Setelah mengadakan penelitian terkait hasil penelitian yang menggunakan tes kemampuan komunikasi matematis siswa pada tanggal 30 Maret 2021. Dengan tes ini dapat mengetahui nilai siswa dan yang tergolong dalam mempunyai kemampuan tinggi, sedang, dan rendah. Berikut ini akan dipaparkan tabel dari hasil nilai tes siswa kelas VIII.IA SMP Negeri 1 Sosorgadong.

Tabel 2

Hasil Nilai Kemampuan Komunikasi Matematis Siswa Berdasarkan Tes

\begin{tabular}{|c|c|c|c|c|c|c|}
\hline \multirow{2}{*}{ No } & \multirow{2}{*}{ Inisial } & \multirow{2}{*}{ Nilai } & \multicolumn{3}{|c|}{ Indikator } & \multirow{2}{*}{$\begin{array}{c}\text { Kategori Kemampuan } \\
\text { Siswa }\end{array}$} \\
\hline & & & 1 & 2 & 3 & \\
\hline 1 & AYS & 58,33 & 1 & 1 & 1 & Sedang \\
\hline 2 & AAS & 50 & 1 & 1 & 1 & Sedang \\
\hline 3 & AS & 66 & 1 & 1 & 1 & Sedang \\
\hline
\end{tabular}


ISSN. 2621-9832

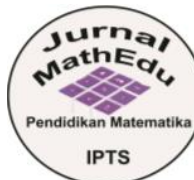

JURNAL MathEdu (Mathematic Education Journal) http://journal.ipts.ac.id/index.php/MathEdu

Vol. 4 No. 3 November 2021

\begin{tabular}{|c|c|c|c|c|c|c|}
\hline 4 & BT & 33,33 & 1 & 1 & 0 & Rendah \\
\hline 5 & $\mathrm{CP}$ & 25 & 0 & 1 & 0 & Rendah \\
\hline 6 & DS & 41,66 & 1 & 1 & 0 & Rendah \\
\hline 7 & DM & 91.66 & 1 & 1 & 1 & Tinggi \\
\hline 8 & EM & 75 & 1 & 1 & 1 & Sedang \\
\hline 9 & GM & 83 & 1 & 1 & 1 & Tinggi \\
\hline 10 & MS & 41,66 & 1 & 0 & 1 & Rendah \\
\hline 11 & NS & 66,66 & 1 & 1 & 1 & Sedang \\
\hline & Jumlah & $\frac{632,3}{11}=57,48$ & & & & Sedang \\
\hline
\end{tabular}

Berdasarkan tabel diatas, mengenai hasil dari soal tes kemampuan komunikasi matematis siswa di SMP Negeri 1 Sosorgadong yang berada pada kategori sedang. Dimana siswa yang memperoleh kategori kemampuan komunikasi matematis nya tinggi, ada siswa yang memperoleh kategori kemampuan komunikasi matematisnya sedang dan ada siswa yang memperoleh kategori kemampuan komunikasi matematisnya rendah. Dimana siswa yang menjawab soal tes dengan menggunakan indikator dari kemampuan komunikasi matematis siswa yaitu : a) menghubungkan benda nyata, gambar, diagram ke dalam ide matematika, b) menjelaskan ide, situasi, relasi matematika secara lisan atau tulisan dengan benda nyata atau gambar, c) menyatakan peristiwa sehari-hari dalam bahasa dan simbol matematik. Melalui tes tersebut, ada tiga soal mengenai materi lingkaran dengan tiga indikator dari kemampuan komunikasi matematis, dimana soal tes tersebut terdiri dari 1 soal satu indikator. Dari hasil jawaban soal siswa diatas menunjukkan rata-rata menjawab soal sesuai dengan indikator dari kemampuan komunikasi matematis.

\section{PEMBAHASAN}

\section{a. Minat Belajar Siswa}

Berdasarkan uraian hasil penelitian, untuk mempermudah peneliti dalam melakukan nilai analisis data, maka peneliti membuat penyajian data dalam bentuk tabel berikut ini.

Tabel 3

Hasil jawaban pernyataan Minat Belajar siswa

\begin{tabular}{llllll}
\hline No & Subjek & SL & SR & KD & TP \\
\hline 1 & DM & 20 & 1 & 2 & 2 \\
\hline 2 & AS & 7 & 7 & 7 & 4 \\
\hline 3 & CP & 6 & 6 & 1 & 12 \\
\hline
\end{tabular}

Pada tabel diatas, siswa yang minat belajarnya ada yang sangat tinggi, ada yang sedang dan ada yang rendah. Dalam menjawab pernyataan dari minat belajar siswa terdiri dari pilihan jawaban yaitu : selalu, sering, kadang-kadang, dan tidak pernah. Dari tabel diatas siswa yang menjawab pernyataan rata-rata menjawab "selalu" adalah siswa yang berkemampuan sangat baik, karena siswa tersebut adalah siswa yang paling juara dikelas, sopan dikelas dan anak yang paling pintar dikelas VIII.IA di SMP Negeri 1 Sosorgadong. Menurut Tanjung, dkk (2021:89) Menyatakan minat belajar terdiri atas : a) Rasa senang terhadap mata pelajaran, b) Rasa ketertarikan siswa terhadap mata pelajaran, dan c) rasa ketertarikan siswa terhadap mata pelajaran. Siswa yang berkemampuan minat belajarnya sedang menjawab cukup banyak pernyataan "Selalu". Karena siswa tersebut adalah siswa yang rajin masuk kelas, tapi mentalnya kurang dalam mengeluarkan pendapat dan bertanya saat belum memahami pelajaran. Dan siswa yang berkemampuan kurang adalah siswa yang paling sedikit dalam menjawab pernyataan "selalu", karena siswa tersebut siswa yang jarang masuk kelas, bodoh, dan murid yang paling nakal dalam kelas. Berdasarkan hasil jawaban siswa pada pernyataan tabel diatas terlihat bahwa siswa yang berkemampuan sangat baik, siswa yang berkemampuan sedang, dan siswa yang berkemampuan rendah. Menurut Achru (2019:208) menyatakan bahwa "Minat belajar tidak hanya tergantung pada kemampuan, namun juga bergantung pada apakah seseorang memilih tujuan penguasaan (tujuan baik, atau tujuan kinerja, yang fokusnya adalah mendemonstrasikan atau memperlihatkan kemampuan kita pada orang lain".

\section{b. Kemampuan Komunikasi Matematis}

Kemampuan komunikasi matematis adalah salah satu kemampuan yang perlu dikembangkan. Kemampuan komunikasi seharusnya meliputi berbagai pemikiran, menanyakan pertanyaan, menjelaskan pertanyaan dan memberikan ide-ide, (Tanjung 2018). Hasil penelitian yang telah dianalisis peneliti temukan 
ISSN. 2621-9832

JURNAL MathEdu (Mathematic Education Journal) http://journal.ipts.ac.id/index.php/MathEdu

Vol. 4 No. 3 November 2021

bahwa kemampuan komunikasi matematis siswa di SMP Negeri 1 Sosorgadong di kelas VIII.IA berada pada kategori sedang.

Berikut hasil penelitian dari soal tes kemampuan komunikasi matematis siswa, untuk mempermudah peneliti dalam melakukan analisis data, berikut nama siswa yang yang mewakili yang berkemampuan akademik tinggi, sedang dan rendah. Berikut akan dipaparkan tabel hasil soal tes kemampuan komunikasi matematis siswa kelas VIII.IA di SMP Negeri 1 Sosorgadong.

Tabel 4

Hasil Nilai Berdasarkan Tes Kemampuan Komunikasi Matematis Siswa

\begin{tabular}{llll}
\hline No & Inisial & Nilai & $\begin{array}{l}\text { Kategori } \\
\text { Kemampuan Siswa }\end{array}$ \\
\hline 1 & DM & 91,66 & Tinggi \\
\hline 2 & AS & 66 & Sedang \\
\hline 3 & CP & 25 & Rendah \\
\hline
\end{tabular}

Berdasarkan tabel diatas, Siswa yang di dalam kelas itu ada siswa yang memiliki kemampuanya tinggi, sedang dan rendah tetapi peneliti hanya melakukan anaisis yang mewakili siswa yang berkemampuan tinggi, mewakili siswa yang berkemampuan sedang dan siswa yang mewakili berkemampuan rendah. Siswa yang yang memiliki kemampuan matematisnya tinggi karena siswa tersebut sering mendapat juara satu dikelas, dan anak yang paling rajin dikelas dan saan menjawab soal tes kemmapuan komunikasi matematis siswa yang berkemampuan tinggi, mampu dalam : a) menghubungkan benda nyata, gambar, diagram ke dalam ide matematika, b) menjelaskan ide, situasi, relasi matematika secara lisan atau tulisan dengan benda nyata atau gambar, c) menyatakan peristiwa sehari-hari dalam bahasa dan simbol matematik. Ada siswa yang memiliki kemampuan komunikasi matematis nya sedang karena siswa tersebut jarang dan malu bertanya saat belum memahami materi tersebut tetapi dia anak rajin masuk kelas dan saat menjawab soal tes kemampuan komunikasi matematis siswa cukup mampu dalam : a) menghubungkan benda nyata, gambar, diagram ke dalam ide matematika, b) menjelaskan ide, situasi, relasi matematika secara lisan atau tulisan dengan benda nyata atau gambar, c) menyatakan peristiwa sehari-hari dalam bahasa dan simbol matematik dan ada siswa yang berkemampuan rendah karena siswa tersebut jarang masuk sekolah, anak yg ribut, sering ngantuk dan murid yang paling bandal dikelas dan saan menjawab soal tes kemampuan komunikasi matematis siswa tidak mampu dalam : a) menghubungkan benda nyata, gambar, diagram ke dalam ide matematika, b) menjelaskan ide, situasi, relasi matematika secara lisan atau tulisan dengan benda nyata atau gambar, c) menyatakan peristiwa sehari-hari dalam bahasa dan simbol matematik. Menurut Wihatma dan Rohaeti dalam harahap, dkk (2012:118) menyatakan bahwa "dari hasil observasi di lapangan yang dilakukan olehnya diperoleh informasi bahwa kemampuan komunikasi matematis siswa dalam mengkomunikasikan ide-ide masih kurang sekali”

Berdasarkan tabel diatas, terlihat yang mana siswa yang berkemampua tinggi, siswa yang berkemampuan sedang, dan siswa yang berkemapuan rendah. Oleh karena itu, kemampuan komunikasi matematis hal yang sangat penting dalam pembelajaran matematika dan salah satu kompetensi yang harus dimiliki siswa. Sebagaimana menurut Asikin dalam Wijayanto (2018:98) dan Siregar (2019:86) menyatakan bahwa "kemampuan komunikasi matematis dalam pembelajaran matematika yaitu untuk membantu siswa memnbangun pengetahuan matematiknya, meningkatkan kemampuan pemecahan masalah matematik, memajukan penalaranya, membangun kemampuan diri, meningkatkan keterampilan sosialnya, serta bermamfaat dalam mendirikan komunitas matematik".

\section{c . Ditinjau dari Minat Belajar Siswa Terhadap Kemampuan Komunikasi Matematis}

Berdasarkan hasil penelitian yang telah peneliti temukan bahwa kemampuan komunikasi matematis siswa yang ditinjau dari minat minat belajar siswa di kelas VIII.IA baik dan dilihat dari hasil angket minat belajar siswa baik dan hasil soal tes kemampuan komunikasi matematis sedang terhadap pembelajaran daring dimasa pandemi covid-19. Dimana terlihat bahwa siswa yang berkemampuan minat belajarnya tinggi, yaitu kemampuan komunikasi matematisnya juga tinggi, siswa yang minat belajarnya sedang, yaitu kemampuan komunikasi matematisnya juga sedang, dan siswa yang minat belajarnya rendah, kemampuan komunikasi matematisnya juga rendah. Seperti menurut Ricardo dan Meilani (2017:193) dan Widodo (2012) menyatakan bahwa "hasil belajar merupakan akumulasi pembelajaran yang didapatkan oleh siswa selama proses pembelajaran sehingga siswa dapat mengetahui, memahami, serta mengaplikasikan pengetahuan yang diterimany".

Pengaruh dari minat belajar siswa sangat besar pengaruhnya terhadap hasil belajar matematika siswa, karena dengan adanya minat belajar dalam diri seseorang akan melahirkan perhatian untuk melakukan sesuatu dengan tekun dalam jangka waktu yang lama, lebih konsentrasi, mudah untuk mengingat dan tidak mudah bosan 
ISSN. 2621-9832

JURNAL MathEdu (Mathematic Education Journal) http://journal.ipts.ac.id/index.php/MathEdu

Vol. 4 No. 3 November 2021

dengan apa yang dipelajari. Serta siswa yang memiliki motivasi belajar yang tinggi akan lebih tekun belajar dan akan lebih giat belajar untuk mencapai hasil matematika yang lebih baik. Siswa harus memiliki dan motivasi dalam setiap pembelajaran, karena untuk mencapai tujuan belajar dengan hasil belajar yang baik menurut Pasaribu (2020) dan Damis (2018).

\section{KESIMPULAN}

Berdasarkan hasil penelitian maka peneliti menyimpulkan hasil dari kemampuan komunikasi matematis siswa dan minat belajar siswayang mewakili siswa berkemampuan tinggi, sedang dan rendah yaitu sebagai berikut : Siswa yang memiliki kemampuan akademik matematika tinggi memperoleh skor rata-rata 91,66 yang berada pada kategori "tinggi" dan memiliki tingkat kemampuan komunikasi matematis siswa yang baik karena mampu dalam : a )menghubungkan benda nyata, gambar, tabel, dan diagram ke dalam ide matematika, b) menjelaskan ide, situasi, dan relasi matematika secara lisan atau tulisan dengan benda nyata dan gambar dan c) menyatakan peristiwa sehari-hari dalam bahasa atau simbol matematis. Sehingga dapat disimpulkan bahwa siswa memiliki kemampuan komunikasi matematis siswa yang sangat sangat baik memiliki minat belajar dalam pembelajaran daring dimasa pandemi covid-19. Siswa yang memiliki kemampuan akademik matematika sedang memperoleh skor rata-rata 66 yang berada pada kategori "sedang" dan memiliki tingkat sedang memiliki tingkat kemampuan komunikasi yang baik karena belum sepenuhnya mampu a)menghubungkan benda nyata, gambar, tabel, dan diagram ke dalam ide matematika, b) menjelaskan ide, situasi, dan relasi matematika secara lisan atau tulisan dengan benda nyata dan gambar dan c) menyatakan peristiwa sehari-hari dalam bahasa atau simbol matematis. Sehingga dapat disimpulkan bahwa siswa yang memiliki tingkat kemampuan komunikasi matematis yang baik juga belum sepenuhnya memiliki minat belajar pada pembelajaran daring di masa pandemi covid-19. Dan Siswa yang memiliki kemampuan akademik matematika rendah memperoleh skor 25 yang berada pada kategori "rendah" dan memiliki tingkat kemampuan komunikasi yang kurang karena belum mampu a)menghubungkan benda nyata, gambar, tabel, dan diagram ke dalam ide matematika, b) menjelaskan ide, situasi, dan relasi matematika secara lisan atau tulisan dengan benda nyata dan gambar dan c) menyatakan peristiwa sehari-hari dalam bahasa atau simbol matematis. Sehingga dapat disimpulkan bahwa siswa yang memiliki tingkat kemampuan komunikasi matematis yang rendah juga belajar siswa yaitu pada tahap : a) perhatian, b) ketertarikan, c) rasa senang, d) keterlibatan. Oleh sebab itu pentingnya kesadaran dari dalam diri siswa untuk memperhatikan kemampuan komunikasi matematisnya yang tidak terlepas dari peran guru untuk menumbuhkan kemampuan komunikasi belum memiliki minat belajar pada pembelajaran daring di masa pandemi covid-19.

\section{IMPLIKASI}

Dari kesimpulan diatas, maka dapat ditarik implikasi bahwa kemampuan komunikasi matematis sangat mendukung minat belajar siswa. Adapun tahapan kemampuan komunikasi matematis yang diperlukan yaitu : mampu a)menghubungkan benda nyata, gambar, tabel, dan diagram ke dalam ide matematika, b) menjelaskan ide, situasi, dan relasi matematika secara lisan atau tulisan dengan benda nyata dan gambar dan c) menyatakan peristiwa sehari-hari dalam bahasa atau simbol matematis. Sehingga dapat meningkatkan minat matematis tersebut, yang akan berdampak pada peningkatan hasil belajar khususnya minat belajar siswa seperti pada hasil yang ditemukan pada penelitian ini yaitu siswa yang memiliki kemampuan komunikasi yang sangat baik akan memiliki minat belajar siswa yang sangat baik.

\section{SARAN}

a. Bagi siswa, bermamfaat untuk menyadarkan bahwa kemampuan komunikasi matematis itu sangat penting untuk meningkatkan hasil belajar matematika serta dapat menumbuhkan semangat dan aktivitas yang tinggi untuk mencapai prestasi yang diinginkan.

b. Bagi guru, bermamfaat untuk menambah informasi dan dapat memberikan masukan untuk meningkatkan kemampuan komunikasi siswa agar dapat memecahkan masalah matematika dengan baik dan benar.

c. Bagi kepala sekolah, dapat menjadi bahan pertimbangan maupun kebijakan dalam pembinaan dan pengembangan kinerja guru.

d. Bagi peneliti, untuk memperdalam pengetahuan, sekaligus menjadi pedoman bagi peneliti selanjutnya yang ingin meneliti tentang kemampuan komunikasi matematis siswa dengan menggunakan informan yang lainya.

\section{REFERENSI}

Achru, Andi. Pengembangan Minat Belajar Dalam Pembelajaran. Jurnal Idaarah. Vol. 3, No. 2. Hal 208. Arikunto, Suharsimi. 2009. Manajemen Penelitian.Jakarta : Rineka Cipta. 
ISSN. 2621-9832

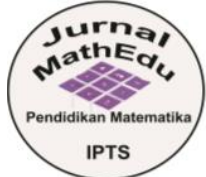

JURNAL MathEdu (Mathematic Education Journal) http://journal.ipts.ac.id/index.php/MathEdu Vol. 4 No. 3 November 2021

Damis dan Muhajis. Analisis Hubungan Antara Motivasi Belajar dan Hasil Belajar Pada Sekolah Dasar Negeri 3 Allangkuang Kecamatan Maritenggae Kabupaten Sindereng Rappang. Jurnal Idaarah. Vol. 2, No. 2. Hal 217.

Harahap, Rizky Aisyah dan Harahap, Syahril Muhammad. 2018. Efektivitas Penggunaan Construcctivism Approach Terhadap Kemampuan Komunikasi Matematis Siswa Di Kelas XI SMA NEGERI 7 Padangsidimpuan.Jurnal MathEdu (Mathematic Education Journal. Vol. 1. No. 2. Hal 1-2.

Mustakim. 2020. Efektivitas Pembelajaran Daring Menggunakan Media Online Selama Pandemi Covid-19 Pada Mata Pelajaran Matematika. Journal Of Islamic Education. Vol. 2, No. 1. Hal 2- 4...

Raja, Andika. Ahmad, Marzuki dan Lubis, Roslian. 2020. Efektivitas Penggunaan Pendekatan Open-Ended Terhadap Kemampuan Komunikasi Matematis Siswa Di Kelas X SMA Negeri Sibabangun. Jurnal MathEdu (Mathematic Education Journal). Vol. 3, No. Hal 10- 15. Hal 9-10.

Ricardo, Meilani dan Intansari, Rini. 2017. Impak Minat dan Motivasi Belajar Terhadap Hasil Belajar Siswa. Jurnal Pendidikan Manajemen Perkantoran. Vol. 2, No. 2. Hal 190-195.

Senjayati, Eka. 2015. Penerapan Pendekatan Kontekstual Untuk Meningkatkan Kemampuan Komunikasi Matematik Siswa Smk Di Kota Cimahi.Jurnal Ilmiah STKIP Siliwangi Bandung. Vol. 9, No. 1. Hal 34-36

Silalahi, Ulber. 2012. Metode Penelitian Sosial. Bandung : Refika Aditama.

Siregar, Fuziah Nur. 2019. Nur Kemampuan Komunikasi Matematis Dalam Pendekatan Matematika Realistik Di Sekolah Dasar. Jurnal Pendidikan Dasar. Vol. 3, No. 1. Hal 85.

Sugiyono. 2014. Metode Penelitian Manajemen. Bandung: Alfabeta, CV.

Sugiyono. 2014. Memahami Penelitian Kualitatif. Bandung : Alfabeta, CV.

Tanjung, Wahyuni Eva. 2018.Efektivitas Model Pembelajaran Two Stay Terhadap Kemampuan Komunikasi Matematis Siswa Di Kelas X IPA SMA Negeri 1 Kolang. Jurnal MathEdu (Mathematic Education Journal. Vol. 1, No. 1. Hal 53-54.

Widayanti, Lusi Widodo. Peningkatan Aktivitas Belajar Dan Hasil Belajar Siswa Dengan Metode Problem Based Learning Pada Siswa Kelas VII MTS Negeri Donomulyo Kulon Progo Tahun 2012/2013. Jurnal Fisika Indonesia. Vol. 49, No. 17. Hal 34.

Wijayanto, Dwi Agus. Fajriah, Nurul Siti dan Anita, Wahyu Ika. Analisis Kemampuan Komunikasi Matematis Siswa SMP pada Materi Segitiga Dan Segi Empat. Jurnal Cendekia. Jurnal Pendidikan Matematika. Vol. 2, No. 1. Hal 98. 